\title{
Kualitas Semen Beku Kambing Peranakan Boer yang Dikriopreservasi dengan Pengencer Tris Kuning Telur dan Berbagai Konsentrasi Ekstrak Daun Kelor
}

\author{
(THE QUALITY OF BOER CROSSBREED GOAT FROZEN SEMEN \\ CRYOPRESERVED WITH EGG YOLK TRIS EXTENDER AND \\ VARIOUS CONCENTRATIONS OF MORINGA LEAF EXTRACT)
}

\author{
Muhammad Rizal ${ }^{1 *}$, Chatimatun Nisa ${ }^{2}$, Ririn Norliani ${ }^{3}$ \\ ${ }^{1}$ Program Studi Peternakan, ${ }^{2}$ Program Studi Agronomi, \\ ${ }^{3}$ Mahasiswi Program Studi Peternakan, \\ Fakultas Pertanian, Universitas Lambung Mangkurat, \\ Jl. Jenderal Ahmad Yani Km. 36 \\ Banjarbaru, Kalimantan Selatan, Indonesia 70714, \\ *E-mail: mrizal@ulm.ac.id
}

\begin{abstract}
ABSTRAK
Daun kelor mengandung berbagai zat nutrien yang dapat melindungi spermatozoa selama kriopreservasi semen. Tujuan penelitian ini adalah untuk menguji pengaruh ekstrak daun kelor di dalam pengencer tris kuning telur terhadap kualitas semen beku kambing peranakan Boer. Semen segar dibagi ke dalam empat buah tabung reaksi dengan volume yang sama, kemudian disentrifugasi dengan kecepatan 3.000 RPM selama 20 menit. Plasma semen dibuang, dan sedimen (spermatozoa) diencerkan dengan empat pengencer berbeda sebagai perlakuan. Penelitian menggunakan rancangan acak lengkap dengan empat perlakuan, yakni: $73 \%$ pengencer dasar tris $+20 \%$ kuning telur $+7 \%$ gliserol tanpa ekstrak daun kelor (kontrol), $71 \%$ pengencer dasar tris $+20 \%$ kuning telur $+7 \%$ gliserol $+2 \%$ ekstrak daun kelor (EDK2), $69 \%$ pengencer dasar tris $+20 \%$ kuning telur + 7\% gliserol + 4\% ekstrak daun kelor (EDK-4), dan 67\% pengencer dasar tris $+20 \%$ kuning telur $+7 \%$ gliserol $+6 \%$ ekstrak daun kelor (EDK-6). Semen dikemas di dalam straw mini, diekuilibrasi di dalam lemari es pada suhu $5^{\circ} \mathrm{C}$ selama empat jam dan dibekukan dengan cara meletakkan straw $10 \mathrm{~cm}$ di atas permukaan nitrogen cair selama 15 menit. Peubah yang diamati adalah persentase motilitas, persentase hidup, dan persentase membran plasma utuh (MPU) spermatozoa dievaluasi setelah pengenceran dan thawing. Hasil penelitian menunjukkan bahwa penambahan ekstrak daun kelor ke dalam pengencer tris kuning telur dapat mempertahankan kualitas spermatozoa semen beku kambing peranakan boer. Penambahan sebanyak 4\% ekstrak daun kelor merupakan konsentrasi terbaik dalam menghasilkan semen beku kambing peranakan boer. Persentase motilitas spermatozoa setelah thawing pada perlakuan kontrol, EDK-2, EDK-4, dan EDK-6 masing-masing adalah 41,25\%, 45\%, 50\%, dan 47,5\%. Dapat disimpulkan bahwa penambahan 4\% ekstrak daun kelor ke dalam pengencer tris kuning telur merupakan konsentrasi terbaik dalam menghasilkan semen beku kambing peranakan boer.
\end{abstract}

Kata-kata kunci: Ekstrak daun kelor, kriopreservasi semen, kambing peranakan boer.

\begin{abstract}
Moringa leaves contain various nutrients that can protect spermatozoa during semen cryopreservation. The purpose of this study was to examine the effectivity of Moringa leaf extract into egg yolk tris extender on the quality of Boer crossbreed goat frozen semen. Fresh semen was divided into four tubes in equal volume, and centrifuged with 3,000 RPM for 20 minutes. Seminal plasma was removed, and pellet (spermatozoa) was diluted with four different extenders as a treatment. The study used a completely randomized design with four treatments, namely: $73 \%$ tris-based extender $+20 \%$ egg yolk $+7 \%$ glycerol (control), $71 \%$ tris-based extender $+20 \%$ egg yolk $+7 \%$ glycerol $+2 \%$ Moringa leaf extract daun kelor (MLE2), $69 \%$ tris-based extender $+20 \%$ egg yolk $+7 \%$ glycerol $+4 \%$ Moringa leaf extract (MLE- 4 ), and $67 \%$ trisbased extender $+20 \%$ egg yolk $+7 \%$ glycerol $+6 \%$ Moringa leaf extract (MLE-6), respectively. Diluted-
\end{abstract}


semen were loaded into mini straw $(0.25 \mathrm{ml})$, equilibrated in the refrigerator at $5^{\circ} \mathrm{C}$ for four hours and frozen by placing the straw $10 \mathrm{~cm}$ above the liquid nitrogen surface for 15 minutes. Variables including percentage of spermatozoa motility, live, and intact plasma membrane (IPM) were evaluated after dilution and thawing. Results of this study showed that the addition of Moringa leaf extract into egg yolk tris extender was able to maintain the quality of Boer crossbreed goat frozen semen. The addition of $4 \%$ Moringa leaf extract was the best concentration in producing frozen semen of Boer crossbreed goat. The percentage of spermatozoa motility after thawing in the control, MLE-2, MLE-4, and MLE-6 were 41.25\%, $45 \%, 50 \%$, and $47.5 \%$, respectively. In conclusion, the addition of $4 \%$ Moringa leaf extract into egg yolk tris extender is the best concentration in producing frozen semen of Boer crossbreed goat.

Key words: Moringa leaf extract, semen cryopreservation; Boer crossbreed goat.

\section{PENDAHULUAN}

Kambing boer merupakan kambing tipe pedaging dengan konformasi tubuh yang baik, mudah beradaptasi terhadap perubahan suhu lingkungan dan lebih resistan terhadap penyakit (Malan, 2000). Kambing boer berasal dari Afrika Selatan, dan diimpor dengan tujuan untuk memperbaiki performa kambing lokal Indonesia. Menurut Inounu et al. (2002) salah satu cara untuk meningkatkan produktivitas ternak adalah dengan memasukkan pejantan unggul dari luar, kemudian dilakukan kawin silang. Hasil penelitian menunjukkan bahwa persilangan antara kambing kacang dan pejantan kambing boer mampu meningkatkan produktivitas (bobot lahir, bobot sapih, litter size anak, dan kenaikan bobot badan) sebesar 30$45 \%$ dibandingkan dengan kambing kacang (Elieser et al., 2003).

Salah satu cara yang dapat dilakukan untuk mempercepat peningkatan populasi dan perbaikan mutu genetik kambing lokal adalah dengan penerapan teknologi inseminasi buatan (IB), menggunakan semen kambing boer. Melalui teknologi IB, potensi reproduksi jantan unggul dapat dioptimalkan. Salah satu teknologi yang terintegrasi dengan IB adalah teknologi pengolahan semen. Tujuan utama pengolahan semen adalah meningkatkan kapasitas semen untuk melayani lebih banyak ternak betina. Untuk mencapai tujuan ini, semen diencerkan dengan bahan-bahan pengencer tertentu, yang memenuhi syarat seperti: memiliki sumber energi, penyangga, tidak toksik, mencegah kerusakan pada spermatozoa, murah, dan mudah diperoleh (Toelihere, 1993). Menurut Rizal et al. (2003) satu kali ejakulasi pejantan domba memiliki kemampuan melayani sekitar 35 ekor betina jika menggunakan program IB, dengan menggunakan semen beku yang dikemas di dalam straw mini; dibandingkan dengan jika kawin alam satu ejakulasi hanya untuk melayani satu ekor betina.

Kualitas semen hasil olahan merupakan salah satu faktor penting yang menentukan keberhasilan aplikasi teknologi IB (Tamoes et al., 2014). Kualitas semen hasil olahan dapat dipertahankan dengan menambahkan berbagai senyawa aditif ke dalam pengencer semen, di antaranya adalah ekstrak daun kelor. Ekstrak daun kelor memungkinkan digunakan sebagai salah satu komponen bahan pengencer semen. Daun kelor mengandung antioksidan yang tinggi (Kasolo et al., 2010) dan antibakteri (Das et al., 2012). Senyawa yang bersifat antioksidan dapat menghambat kerja radikal bebas dalam merusak membran plasma sel spermatozoa selama preservasi semen (Sitepu et al., 2018), sehingga mampu mempertahankan kualitas spermatozoa. Menurut Kumala et al. (2016) daun kelor mengandung senyawa flavonoid yang mampu mengikat radikal bebas. Perbaikan kualitas semen yang dipreservasi dengan pengencer yang disuplementasi ekstrak daun kelor dilaporkan pada spermatozoa sapi (Sokunbi et al., 2015) dan pada spermatozoa babi landrace (Fafo et al., 2016).

Penelitian ini bertujuan untuk menguji pengaruh berbagai konsentrasi ekstrak daun kelor di dalam pengencer tris kuning telur terhadap kualitas semen beku kambing peranakan boer. Diharapkan senyawa yang terkandung di dalam ekstrak daun kelor mampu melindungi kerusakan sel spermatozoa dari kerusakan selama proses kriopreservasi, sehingga kualitasnya dapat dipertahankan dan memenuhi syarat digunakan dalam program IB.

\section{METODE PENELITIAN}

\section{Koleksi dan Kriopreservasi Semen}

Semen dikoleksi dari dua ekor kambing peranakan boer jantan dewasa menggunakan 
vagina buatan. Semen segar segera dievaluasi kuantitas dan kualitasnya, meliputi: volume, kekentalan (konsistensi), derajat keasaman $(\mathrm{pH})$, gerakan massa spermatozoa, konsentrasi spermatozoa, persentase motilitas spermatozoa, persentase hidup spermatozoa, persentase abnormalitas spermatozoa, dan persentase membran plasma utuh (MPU). Semen segar yang memenuhi syarat, yakni memiliki persentase motilitas spermatozoa $>75 \%$ (Salmani et al., 2014), konsentrasi spermatozoa e" $2.000 \times 10^{6} \mathrm{sel} / \mathrm{mL}$ dan persentase abnormalitas spermatozoa $<15 \%$ ) (Bearden dan Fuquay, 1997), dan persentase MPU >60\% (Revell dan Mrode, 1994) diproses untuk disimpan sebagai semen beku.

Semen segar dibagi ke dalam delapan buah tabung reaksi dengan volume yang sama, kemudian disentrifugasi dengan kecepatan 3.000 rpm selama 20 menit dan plasma semen dibuang. Pelet berupa spermatozoa (sedimen) masingmasing diencerkan menggunakan pengencer dengan komposisi yang berbeda sebagai perlakuan, yakni: 73\% pengencer dasar tris + $20 \%$ kuning telur $+7 \%$ gliserol tanpa ekstrak daun kelor (kontrol), 71\% pengencer dasar tris $+20 \%$ kuning telur $+7 \%$ gliserol $+2 \%$ ekstrak daun kelor (EDK-2), 69\% pengencer dasar tris + $20 \%$ kuning telur $+7 \%$ gliserol $+4 \%$ ekstrak daun kelor (EDK-4), dan 67\% pengencer dasar tris $+20 \%$ kuning telur $+7 \%$ gliserol $+6 \%$ ekstrak daun kelor (EDK-6). Semen diencerkan hingga mencapai konsentrasi 200 juta spermatozoa motil per mililiter. Penelitian ini menggunakan rancangan acak lengkap (RAL) dengan empat perlakuan dan enam kali ulangan.

Komposisi pengencer dasar tris terdiri atas: $3,32 \mathrm{~g}$ tris $+1,86 \mathrm{~g}$ asam sitrat $+1,24 \mathrm{~g}$ fruktosa dilarutkan dengan akuabidestilata hingga mencapai volume $100 \mathrm{~mL}$. Pengencer ditambahkan antibiotik berupa 1.000 IU penisilin dan $1.000 \mu \mathrm{g}$ streptomisin setiap milliliter pengencer. Daun kelor diekstrak dengan metode rotary vacuum evaporator (Sokunbi et al., 2015; Kumala et al., 2016). Ekstrak daun kelor disimpan di dalam freezer sebelum digunakan.

Semen yang telah diencerkan dikemas di dalam straw mini $(0,25 \mathrm{~mL})$. Semen yang telah dikemas tersebut diekuilibrasi di dalam refrigerator lemari es pada suhu $5^{\circ} \mathrm{C}$ selama empat jam. Pembekuan semen dilakukan dengan cara meletakkan straw $10 \mathrm{~cm}$ di atas permukaan nitrogen cair di dalam styrofoam yang ditutup rapat (suhu sekitar $-130^{\circ} \mathrm{C}$ ) selama
15 menit. Selanjutnya straw dimasukkan ke dalam nitrogen cair (suhu sekitar $-196^{\circ} \mathrm{C}$ ) dan disimpan di dalam kontainer nitrogen cair. Setelah disimpan selama tujuh hari, setiap sampel straw masing-masing perlakuan dicairkan kembali (thawing) untuk dievaluasi kualitasnya. Semen beku dicairkan kembali dengan cara memasukkan straw ke dalam air bersuhu $37^{\circ} \mathrm{C}$ selama 30 detik.

\section{Peubah yang Diamati}

Peubah kualitas spermatozoa yang diamati adalah: persentase motilitas spermatozoa, persentase hidup spermatozoa, dan persentase MPU masing-masing setelah tahap pengenceran dan thawing.

Persentase Motilitas Spermatozoa. Persentase spermatozoa yang bergerak progresif (bergerak ke depan). Dievaluasi secara subjektif pada delapan lapang pandang yang berbeda dengan mikroskop pembesaran 400 kali (Rasul et al., 2001).

Persentase hidup spermatozoa: persentase spermatozoa yang hidup dievaluasi dengan pewarnaan eosin-nigrosin (Felipe-Perez et al., 2008). Spermatozoa yang hidup ditandai oleh kepala berwarna putih, sedangkan yang mati ditandai oleh kepala berwarna merah. Sebanyak minimum 200 spermatozoa dievaluasi dengan mikroskop pembesaran 400 kali.

Persentase MPU. Persentase spermatozoa yang memiliki membran plasma utuh. Dievaluasi dengan metode hypoosmotic swelling (HOS) test (Revell dan Mrode, 1994). Komposisi larutan hipoosmotik terdiri atas: $0,9 \mathrm{~g}$ fruktosa $+0,49$ g natrium sitrat yang dilarutkan dengan akuabidestilata hingga mencapai volume 100 $\mathrm{mL}$. Sebanyak $100 \mathrm{~mL}$ larutan hipoosmotik ditambahkan dengan $10 \mathrm{~mL}$ semen dan dicampur hingga homogen kemudian diinkubasi pada suhu $37^{\circ} \mathrm{C}$ selama 45 menit. Preparat ulas tipis dibuat pada gelas objek kemudian dievaluasi dengan mikroskop pembesaran 400 kali terhadap minimum 200 spermatozoa. Spermatozoa yang memiliki membran plasma utuh ditandai oleh ekor melingkar atau menggelembung, sedangkan yang rusak ditandai oleh ekor lurus.

\section{Analisis Data}

Data dianalisis dengan analisis ragam. Perbedaan antar perlakuan diuji dengan uji beda nyata terkecil (BNT) (Steel dan Torrie, 1993). Data diolah menggunakan program SAS statistical software (SAS 9.1, 2001). 


\section{HASIL DAN PEMBAHASAN}

Karakteristik Semen Segar KambingxBoer

Volume semen yang didapatkan pada penelitian ini rata-rata $0,61 \mathrm{ml}$ dengan kisaran 0,4-1 ml (Tabel 1). Hasil penelitian sebelumnya dilaporkan bahwa volume semen kambing Boer rata-rata sebanyak 0,96 $\mathrm{ml}$ (Putra et al., 2012), $1,05 \mathrm{ml}$ (Rosmaidar et al., 2013), dan $1 \mathrm{ml}$ (Lestari et al., 2014). Menurut Hafez dan Hafez (2000), volume semen kambing setiap ejakulat berkisar antara 0,8-1,2 ml. Jumlah volume semen ternak bergantung pada bangsa, umur, ukuran badan, tingkatan makanan, dan frekuensi penampungan (Feradis, 2010).

Konsentrasi spermatozoa yang diperoleh pada penelitian ini adalah rata-rata $4.260 \mathrm{juta} /$ ml. Hasil yang diperoleh lebih tinggi dibandingkan dengan yang dilaporkan peneliti sebelumnya. Konsentrasi spermatozoa kambing Boer rata-rata $2.170 \mathrm{juta} / \mathrm{ml}$ (Rosmaidar et al., 2013) dan 4.190 juta/ml (Lestari et al., 2014). Menurut Rosmaidar et al. (2013) perbedaan konsentrasi spermatozoa disebabkan oleh pola pemeliharaan, umur, dan variasi individu.

Persentase motilitas spermatozoa pada penelitian ini sebesar 78\%. Hasil tersebut lebih rendah dibandingkan dengan hasil penelitian Pamungkas dan Anwar (2013) yaitu 87,66\%, namun lebih tinggi daripada hasil penelitian Munazaroh et al. (2013) yaitu 73,33\%. Menurut Sundararaman dan Edwin (2008), semen yang memiliki kualitas baik dengan motilitas progresif minimum $70 \%$ yang akan dipilih untuk dibekukan. Persentase motilitas yang diperoleh dalam penelitian ini berada pada kisaran normal, sehingga memenuhi syarat untuk diencerkan. Menurut Azzahra et al. (2016), perbedaan umur ternak memberikan pengaruh terhadap motilitas spermatozoa.

Persentase hidup spermatozoa yang didapatkan pada penelitian ini adalah $89,78 \%$. Mugiyati et al. (2017) melaporkan bahwa persentase spermatozoa hidup semen kambing Boer adalah sebanyak 79,81\%. Persentase abnormalitas spermatozoa yang diperoleh ratarata 5,8\%. Hasil yang diperoleh lebih rendah dibandingkan dengan yang dilaporkan oleh Husin et al. (2007) bahwa abnormalitas spermatozoa kambing Boer rata-rata 13,26\%. Persentase abnormalitas spermatozoa yang diperoleh pada penelitian ini masih dalam kisaran yang normal, dan memenuhi syarat untuk digunakan dalam program IB. Menurut Pamungkas dan Anwar (2013), persentase abnormalitas spermatozoa tidak boleh lebih dari $15 \%$.

\section{Kualitas Spermatozoa setelah Kriopre- servasi}

Hasil penelitian menunjukkan bahwa penambahan ekstrak daun kelor di dalam pengencer tris kuning telur dapat meningkatkan kualitas spermatozoa semen beku kambing peranakan Boer. Pada tahap setelah thawing, persentase motilitas, persentase hidup, dan persentase MPU perlakuan EDK-4 (50,00; 63,75; dan $64,25 \%)$ nyata lebih tinggi $(\mathrm{P}<0,05)$ dibandingkan dengan kontrol (41,25; 50,50; dan 47,00\%) (Tabel 2, 3, dan 4). Penambahan ekstrak daun kelor sebanyak 2 dan 6\% tidak secara nyata meningkatkan kualitas semen beku kambing peranakan Boer. Hal ini menunjukkan bahwa penambahan ekstrak daun kelor sebanyak $4 \%$ di dalam pengencer tris kuning telur merupakan konsentrasi terbaik dalam meningkatkan kualitas semen beku kambing peranakan Boer. Hasil pengamatan

Tabel 1. Karakteristik semen segar kambing peranakan Boer

\begin{tabular}{lc}
\hline Variabel & Rata-rata \pm SD \\
\hline Volume semen (ml) & $0,61 \pm 0,22$ \\
Warna semen & Putih susu \\
Derajat keasaman (pH) semen & $6,85 \pm 0,15$ \\
Konsistensi (kekentalan) semen & Kental \\
Gerakan massa spermatozoa & +++ \\
Konsentrasi spermatozoa (juta/ml) & $4.260 \pm 629,54$ \\
Persentase motilitas spermatozoa (\%) & $78,00 \pm 2,74$ \\
Persentase hidup spermatozoa (\%) & $89,78 \pm 2,17$ \\
Persentase abnormalitas spermatozoa (\%) & $5,80 \pm 1,48$ \\
Persentase MPU spermatozoa (\%) & $87,83 \pm 1,17$ \\
\hline
\end{tabular}


Tabel 2. Persentase motilitas spermatozoa kambing peranakan Boer setelah kriopreservasi

\begin{tabular}{|c|c|c|c|c|}
\hline \multirow{2}{*}{ Tahap evaluasi } & \multicolumn{4}{|c|}{ Perlakuan } \\
\hline & Kontrol & EDK-2 & EDK-4 & EDK-6 \\
\hline Pengenceran (\%) & $78,00 \pm 2,74$ & $78,00 \pm 2,74$ & $78,00 \pm 2,74$ & $78,00 \pm 2,74$ \\
\hline
\end{tabular}

Keterangan: ${ }^{a b}$ Superskrip dalam baris yang sama menunjukkan berbeda nyata $(\mathrm{P}<0,05)$ $\mathrm{EDK}=$ ekstrak daun kelor.

Tabel 3. Persentase hidup spermatozoa kambing peranakan Boer setelah kriopreservasi

\begin{tabular}{lcccr}
\hline \multirow{2}{*}{ Tahap evaluasi } & \multicolumn{4}{c}{ Perlakuan } \\
\cline { 2 - 5 } & Kontrol & EDK-2 & EDK-4 & EDK-6 \\
\hline Pengenceran (\%) & $88,25 \pm 1,15$ & $89,73 \pm 1,25$ & $88,99 \pm 1,45$ & $88,97 \pm 1,37$ \\
Thawing (\%) & $50,50 \pm 2,36^{\text {a }}$ & $55,00 \pm 1,41^{\text {ab }}$ & $63,75 \pm 1,26^{\mathrm{c}}$ & $58,00 \pm 1,71^{\mathrm{bc}}$ \\
\hline
\end{tabular}

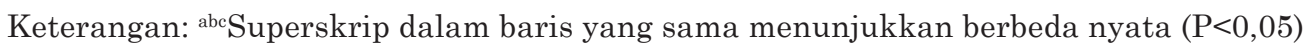

EDK = ekstrak daun kelor.

Tabel 4. Persentase MPU spermatozoa kambing peranakan Boer setelah kriopreservasi

\begin{tabular}{lcccr} 
Tahap evaluasi & Kontrol & EDK-2 & EDK-4 & EDK-6 \\
\cline { 2 - 5 } & & & & \\
\hline Pengenceran (\%) & $86,73 \pm 1,14$ & $87,77 \pm 1,20$ & $87,26 \pm 1,21$ & $86,98 \pm 1,46$ \\
Thawing (\%) & $47,00 \pm 1,41^{\mathrm{a}}$ & $54,75 \pm 1,71^{\mathrm{b}}$ & $63,00 \pm 1,82^{\mathrm{c}}$ & $54,50 \pm 1,29^{\mathrm{b}}$ \\
\hline
\end{tabular}

Keterangan: ${ }^{a b c}$ Superskrip dalam baris yang sama menunjukkan berbeda nyata $(\mathrm{P}<0,05)$ $\mathrm{EDK}=$ ekstrak daun kelor.

juga diperoleh bahwa kualitas pergerakan individu spermatozoa pada perlakuan EDK-4 lebih baik dibandingkan dengan perlakuan lainnya.

Penambahan ekstrak daun kelor dalam pengencer tris kuning telur mampu meningkatkan kualitas semen beku kambing peranakan Boer diduga karena daun kelor mengandung beberapa zat aktif yang melindungi spermatozoa dari kerusakan selama proses kriopreservasi, terutama saat pengenceran, pembekuan dan thawing. Daun kelor mengandung antioksidan yang tinggi dan antibakteri (Kasolo et al., 2010; Das et al., 2012). Menurut Sitepu et al. (2018), senyawa antioksidan dapat menghambat kerja radikal bebas yang dapat merusak spermatozoa, sehingga keutuhan membran plasma sel spermatozoa dapat tetap dipertahankan selama proses kriopresrevasi. Membran plasma sel yang utuh akan berpengaruh positif terhadap persentase motilitas dan kelangsungan hidup spermatozoa. Daun kelor mengandung senyawa yang berfungsi sebagai antioksidan berupa flavonoid, vitamin $\mathrm{C}$ dan vitamin $\mathrm{E}$ (Gopalakrishnan et al., 2016). Vitamin C dapat menangkal radikal bebas dan membuat membran plasma sel spermatozoa terlindungi (Cahyadi et al., 2016). Kumala et al. (2016) menyatakan daun kelor mengandung senyawa flavonoid yang mampu mengikat radikal bebas.

Pengencer semen yang ditambahkan 4-16\% ekstrak daun kelor mampu mempertahankan motilitas, morfologi, dan integritas membran 
plasma sel spermatozoa sapi (Sokunbi et al., 2015). (Fafo et al. (2016) melaporkan bahwa pengencer sitrat kuning telur yang ditambahkan 5\% ekstrak daun kelor efektif mempertahankan motilitas dan viabilitas spermatozoa babi Landrace.

Kualitas semen beku yang lebih rendah pada penambahan $2 \%$ ekstrak daun kelor dibandingkan dengan 4\% menunjukkan bahwa kandungan zat aktif yang terkandung di dalam daun kelor tersebut masih kurang jumlahnya untuk melindungi secara optimal spermatozoa dari kerusakan selama proses kriopreservasi. Hasil yang lebih rendah juga terjadi pada penambahan sebanyak $6 \%$ ekstrak daun kelor, yang diduga akibat terlalu banyaknya kandungan zat aktif daun kelor seperti tannin yang justru merugikan spermatozoa. Oka et al. (2016) melaporkan bahwa ekstrak daun kelor mengandung tannin sebanyak 831,92 mg/100 ml. Menurut Putranti et al. (2010), semakin besar konsentrasi tannin maka dapat menurunkan pH larutan karena tannin mengandung senyawa fenol yang memiliki sifat cenderung asam. Media yang bersifat asam dapat membunuh spermatozoa. Hafez dan Hafez (2000) menyatakan bahwa $\mathrm{pH}$ semen yang normal adalah 7 (netral). Zat terlarut yang terlalu banyak juga akan meningkatkan tekanan osmotik pengencer media, sehingga berdampak buruk terhadap daya hidup spermatozoa (Kulaksiz et al., 2013).

Jika mengacu pada persyaratan kelayakan semen beku kambing menurut standar nasional Indonesia (SNI 4869.3:2014), maka semen beku pada semua perlakuan dalam penelitian ini memenuhi syarat digunakan dalam program IB. Hal ini karena semen beku pada semua perlakuan memiliki persentase motilitas spermatozoa setelah thawing lebih dari $40 \%$.

\section{SIMPULAN}

Penambahan ekstrak daun kelor di dalam pengencer tris kuning telur dapat mempertahankan kualitas semen beku kambing peranakan Boer. Penambahan sebanyak 4\% ekstrak daun kelor merupakan konsentrasi terbaik dalam menghasilkan semen beku peranakan Boer.

\section{SARAN}

Berdasarkan hasil penelitian, disarankan bahwa untuk mempertahankan kualitas semen beku kambing peranakan Boer yang dikriopreservasi menggunakan pengencer tris kuning telur agar ditambahkan dengan ekstrak daun kelor sebanyak $4 \%$.

\section{UCAPAN TERIMA KASIH}

Peneliti mengucapkan terima kasih pada Lembaga Penelitian dan Pengabdian Masyarakat, Universitas Lambung Mangkurat (LPPM ULM) atas pendanaan penelitian dalam skema Program Dosen Wajib Meneliti Tahun 2020 dengan nomor kontrak: 212.181/UN8.2/ PL/2020. Terima kasih disampaikan pada Kepala dan Laboran Laboratorium Produksi Ternak, Program Studi Peternakan, ULM atas fasilitas laboratorium, dan pada peternak kambing yang tergabung di dalam Kelompok Tani Maju Bersama Sejahtera, Desa Cindai Alus, Kabupaten Banjar.

\section{DAFTAR PUSTAKA}

Azzahra FY, Setiatin ET, Samsudewa D. 2016. Evaluasi motilitas dan persentase hidup semen segar sapi PO Kebumen pejantan muda. Jurnal Sain Peternakan Indonesia 11: 99-107.

Bearden HJ, Fuquay JW. 1997. Applied Animal Reproduction Fourth Edition. New Jersey: Prentice Hall, Upper Saddle.

Cahyadi TRT, Christiyanto M, Setiatin ET. 2016. Persentase hidup dan abnormalitas sel spermatozoa kambing Peranakan Ettawa (PE) dengan pakan yang disuplementasikan daun binahong (Anredera cordifolia (Ten) steenis). Animal Agriculture Journal 5: 2332.

Das AK, Rajkumar V, Verma AK, Swarup D. 2012. Moringa oleifera leaves extract: a natural antioxidant for retarding lipid peroxidation in cooked goat meat patties. International Journal of Food Science and Technology 47: 585-591.

Elieser S, Doloksaribu M, Mahmilia F, Tarigan A, Romjali E. 2003. Peningkatan Produktivitas antara Kambing Kacang dan Kambing Boer. Laporan Akhir Kegiatan Penelitian PAATP Tahun 2003. Loka Penelitian Kambing Potong Sei Putih. 
Fafo M, Hine TM, Nalley WMM. 2016. Pengujian efektivitas ekstrak daun kelor dalam pengencer sitrat kuning telur terhadap kualitas semen cair babi landrace. Jurnal Nukleus Peternakan 3: 184-195.

Felipe-Perez YE, Juarez-Mosqueda ML, Hernandez-Gonzalez EO, Valencia JJ. 2008. Viability of fresh and frozen bull sperm compared by two staining techniques. Acta Vet Bras 2: 123-130.

Feradis. 2010. Bioteknologi Reproduksi pada Ternak. Bandung: Alfabeta.

Gopalakrishnan L, Doriya K, Kumar DS. 2016. Moringa oleifera: a review on nutritive importance and its medicinal application. Journal of Food Science and Human Wellness 5: 49-56.

Hafez ESE, Hafez B. 2000. Reproduction in Farm Animals $7^{\text {th }}$ Edition. Baltimore. Lip.pincott Williams \& Wilkins.

Husin N, Suteky T, Kususiyah. 2017. Uji kualitas semen kambing Nubian dan peranakannya (kambing Nubian x PE) serta kambing Boer berdasarkan lama penyimpanan. Jurnal Sain Peternakan Indonesia 2: 57-65.

Inounu I, Hidayati N, Priyanti A, Tiesnamurti B. 2002. Peningkatan produktivitas domba melalui pembentukan rumpun komposit. Laporan Hasil Penelitian Tahun Anggaran 2001. Buku I. Ternak Ruminansia. Balai Penelitian Ternak, Bogor.

Kasolo JN, Bimeya GS, Ojok L, Ochieng J, Okwal-okeng JW. 2010. Phytochemicals and uses of Moringa oleifera leaves in Uganda rural communities. Journal of Medical Plant Research 4: 753-757.

Kulaksiz R, Ari UC, Daskin A, Uner AG. 2013. The effect of different glycerol concentrations on freezeability of semen from angora, kilis, and saanen goats. Slovak J Anim Sci 46: 39-44.

Kumala IN, Masfufatun, Devi DRE. 2016. Potensi ekstrak daun kelor (Moringa oleifera) sebagai hepatoprotektor pada tikus putih (Rattus novergicus) yang diinduksi parasetamol dosis toksis. Jurnal Ilmiah Kedokteran 5: 58-66.

Lestari TPS, Ihsan MN, Isnaini N. 2014. Pengaruh waktu simpan semen segar dengan pengencer andromed pada suhu ruang terhadap kualitas semen kambing Boer. Jurnal Ternak Tropika 15: 43-50.

Malan SW. 2000. The improved boer goat. Small Rum Res 3: 165-170.

Mugiyati, Salim MA, Isnaini N, Susilawati T. 2017. Pengaruh air kelapa merah yang muda dan tua sebagai pengencer terhadap kualitas semen kambing Boer selama penyimpanan dingin. Jurnal Ternak Tropika 18: 20-26.

Munazaroh AM, Wahyuningsih S, Ciptadi G. 2013. The quality of boer goat freezing sperms using mr. frosty equipments with different Andromed equilibration. Jurnal Ternak Tropika 14: 63-71.

Oka AA, Wiyana KA, Sugitha IM, Miwada INS. 2016. Identifikasi sifat fungsional dari daun jati, kelor, dan kayu manis dan potensinya sebagai sumber antioksidan pada edible film. Jurnal Sain Peternakan Indonesia 11: 1-8.

Pamungkas FA, Anwar. 2013. Daya tahan hidup spermatozoa kambing boer dalam pengencer tris kuning telur yang disimpan pada temperatur berbeda. Dalam: Prosiding Seminar Nasional Peternakan dan Veteriner. Bogor, 4-5 Agustus 2013. Bogor (Indonesia). Pusat Penelitan dan Pengembangan Peternakan. Hlm. 331-338.

Putra RP, Wahyuningsih S, Ciptadi G. 2012. The Test Quality of Boer Goat Semen Which Frozen with Mr. Frosty Instrument by Andromed ${ }^{\circledR}$ Diluter at the Storage Temperature of $-45^{\circ} \mathrm{C}$. Universitas Brawijaya, Malang.

Putranti OD, Kustono, Ismaya. 2010. Pengaruh penambahan crude tannin pada sperma cair kambing Peranakan Ettawa yang disimpan selama 14 hari terhadap viabilitas spermatozoa. Buletin Peternakan 341: 1-7.

Rasul Z, Ahmad N, Anzar M. 2001. Changes in motion characteristics, plasma membrane integrity and acrosome morphology during cryopreservation of buffalo spermatozoa. $J$ Androl 22: 278-283.

Revell SG, Mrode RA. 1994. An osmotic resistance test for bovine semen. Anim Reprod Sci 36: 77-86. 
Rizal M, Toelihere MR, Yusuf TL, Purwantara B, Situmorang P. 2003. Karakteristik penampilan reproduksi pejantan domba garut. Jurnal Ilmu Ternak dan Veteriner 8: 134-140.

Rosmaidar, Dasrul, Lubis TM. 2013. Pengaruh penambahan sari buah tomat dalam media pengencer terhadap motilitas dan viabilitas spermatozoa kambing Boer yang disimpan pada suhu $3-5^{\circ} \mathrm{C}$. Jurnal Ilmiah Peternakan 1: 7-17.

Salmani H, Towhidi A, Zhandi M, Bahreini M, Sharafi M. 2014. In vitro assessment of soybean lecithin and egg yolk based diluents for cryopreservation of goat semen. Cryobiology 68: 276-280.

Sitepu SA, Udin Z, Jaswandi, Hendri. 2018. Quality differences of Boer liquid semen during storage with addition sweet orange essential oil in tris yolk and gentamicin extender. Journal of Community Service and Research 1: 78-82.

Standar Nasional Indonesia (SNI). 2014. Semen Beku Bagian 3: Kambing dan Domba (SNI 4869.3-2014). Jakarta. Badan Standardisasi Nasional.
Steel RGD, Torrie JH. 1993. Prinsip dan Prosedur Statistika. Jakarta. Gramedia Pustaka Utama.

Sokunbi OA, Ajani OS, Lawanson AA, Amao EA. 2015. Antibiotic potential of moringa leaf (Moringa oleifera Lam) crude extract in bull semen extander. European Journal of Medicinal Plants 9: 1-8.

Sundararaman MN, Edwin MJ. 2008. Changes in motility characteristics of goat spermatozoa during glycerol-equilibration and relevance to cryopreservation. Asian Journal of Cell Biology 3: 22-33.

Tamoes JA, Nalley WMM, Hine TM. 2014. Fertilitas spermatozoa babi Landrace dalam pengencer modifikasi zorlesco dengan susu kacang kedelai. Jurnal Sains Peternakan 12: 20-30.

Toelihere MR. 1993. Inseminasi Buatan pada Ternak. Bandung. Angkasa. 